\title{
REDUCING RUNOFF VOLUME BY INCREASING RAINFALL INFILTRATION IN THE INFLITRATION WELLS IN BANDUNG BASIN
}

\author{
Dede Sugandi ${ }^{1}$, Somantri $\mathrm{L}^{1}$, Setiawan $\mathrm{I}^{1}$ \\ ${ }^{1}$ Department of Geography Education, Indonesia University of Education \\ dedesugandi@upi.edu; lilisomantri@upi.edu; iwan4671@gmail.com
}

\begin{abstract}
Development that is not in balance with the environment will create environmental damages. More specifically, it will impact negatively on the environment, such as causing floods. The research attempts to: 1) Calculate rainfall volumes; 2)Analyze efforts of reducing flood volumes and increasing infiltration; and 3)Analyze forms of conservation to reduce flood volumes by increasing infiltration in Bandung Basin. The research employed an exploratory method because data were obtained through surveys and measurements in the field. Rainfall intensity was measured with the formula of $R i=L \times T$; and to calculate rainfall volumes, the formula used was $V=$ $R \times A$. Flood can occur when the capacity of a river is insufficient for the large volumes of rainfall. Land uses, especially in developed lands, cause rainfall to runoff. The total area of developed lands in Bandung is $535,155,000 \mathrm{~m}^{2}$ with a rainfall of $25.6 \mathrm{~mm} /$ hour, resulting in the runoff volume of $13,699,968 \mathrm{~m}^{3}$. The runoff should be infiltrated into the ground by infiltration wells, with an assumption that each $100 \mathrm{~m}^{2}$ building area is able to infiltrate $8.96 \mathrm{~m}^{3}$ of rainwater. With the participation of the population in rain water infiltration, runoff will not occur, thus minimizing the risk of small flood.
\end{abstract}

Keywords: Developed lands, flood, runoff, and infiltration wells.

\section{INTRODUCTION}

\subsection{Area Development}

Development is intended to increase the society's ability and potentials to meet their needs and sustain their life. With the increasing needs of the society, development has come to increasingly neglect the environment's carrying capacity. Urban population growth in particular has continued to increase due to natural growth and urbanization. Population growth demands the fulfillment of the need for the development of residential buildings, social facilities and settlements. These developments cause land to become watertight which has an impact on increased surface flow (Putro and Hayati, 2007; Wiryono, 2007; Weng., 2001). As the human population increases, the demand for food rises. People must either grow food themselves or purchase it. Most people in the developed world purchase what they need and have more than enough to eat (Enger et al., 2006). In addition, in urban environment, especially in the trans-urban regions, the changes in land-cover features are quite frequent and substantial (Prakash et al., 2015). The environment in this regard can be defined as the surroundings in which an entity operates. This includes air, water, land, natural resources, flora, fauna, humans and their interrelation (Sawant., 2013). Urban population growth is hand in hand with urban runoff pollution and damages to the environment. Urban runoff pollution is caused when the runoff, while traveling across the urban environment, acquires contaminants that affect water quality (Waters et al., 2011). Decreased environmental carrying capacity has both direct and indirect impacts on human beings, such as flood and landslide.

The impacts of development are felt by the society to the extent that the environment may become an obstacle in the sustainable fulfillment of a decent life. The sustainability of an environment is marked by its management, in which the environment can provide space, comfort, and safety, and not pose any negative impacts. Achieving sustainable development requires collaboration between different sectors and institutions, as well as the participation of all relevant stakeholders and individuals (Mohsen et al., 2013). Sustainable development is a pattern of resource use that aims to meet human 
needs while preserving the environment so that these needs can be met not only in the present, but in

50 the indefinite future. Sustainability is a process which tells of a development of all aspects of human

51 life affecting sustenance (Sefouhi., 2010).

52 Human beings live in a certain area to meet their needs. In order to meet their needs, human beings

53 have to utilize the land, causing disturbance to the stability and equilibrium of the environment

54 (Iskandar and Sugandi., 2015). Changes in land cover have an impact on the hydrological unit on the 55 hydrological cycle and water quality. They can cause floods, droughts, and changes in rivers and 56 groundwater regimes that affect water quality. Hydrological units where water flows, downhill results in 57 an increase in water runoff. The dynamics of runoff can be predicted by forecasting and simulating 58 future land use (Sanjay et al., 2010; Meyer and Turner., 1998; Prasena and Shrestha., 2013). Increased needs prompt changes in land use for various activities, housing, and general and social facilities. Changes in land use resulting from the various activities cause environmental imbalance.

\subsection{Sustainable Development}

62 Development that is not accompanied by efforts of creating a balance in the environment will lead to 63 environmental damage. Declining environmental or ecosystem's quality is increasingly felt and has 64 both direct and indirect impacts on the economic, social, and cultural aspects of life (Sukojo., 2003). sustainable water system. Sustainable water systems often comprise complex combinations of traditional and new system components that mimic natural processes. These green systems aim to protect public health and safety, and restore natural and human landscapes (Scholz., 2013; Gogate and Rawal., 2013). Without such sustainable water systems, a habitat or an environment is more prone to disasters such as flood and landslide. Floods are the most damaging phenomena that affect the social and economy of the population (Smith and Ward., 1998). The most frequent problem in the urban areas as a result of rapid economic growth and development is flooding (Koyari et al., 2012). Urban floods may be caused by high rain intensity. Time of Concentration (ToC) of each rainfall is a determining factor for selecting rainfall intensity for each watershed. Rainfall intensity that is equal to or slightly less than the ToC is rainfall intensity that will have the full watershed contribution to the runoff at the outlet (Idowu et., 2013). Flood and waterlogged disaster in the Dongting Lake, for instance, is due to the influence of artificial and natural factors such as abnormal atmospheric circulation and influence of land use change. Gradual loss of biodiversity and disturbances in ecological balance are due to the ecological succession from sand deposit to vegetation (Habiyakare et al., 2015). Because the sustainability of life is influenced by environmental sustainability, the environment should be maintained and protected. Collaborative conservation strategies for protecting and managing natural resources help in creating a healthy eco-system. A collaborative approach gives a chance in which conservation issues are targeted collectively by using an adaptive management of whole ecosystems, including human communities (Singh et al., 2014). Developing, testing and implementing indicators to identify and assess vulnerability to floods are an important prerequisite for effective disaster risk reduction (Sanayanbi et al., 2014). Conservation is closely related to the socio-economy of the inhabitants. If the land is damaged, the sustainability of the resources will decrease and eventually this will impact on the sustainability of life and development (Klijn et al., 2015; Sugandi., 2014). In addition, climate change may affect the sustainability of a certain environment. For example, the climate change affects the Sundarbans Mangrove forest through changing its biodiversity composition in terms of loss of wildlife habitats which is responsible for accelerating tiger human conflicts (Haque et al., 2015). 
The above statements show that human beings live in an environment, but if the environment in which they are living continues to experience damages, the sustainability of their life will be negatively affected. In other words, the sustainability of human life is really dependent upon environmental sustainability. Therefore, human beings as a component of the environment should always maintain the equilibrium. Environmental equilibrium requires human beings to utilize the environment wisely.

\subsection{Land Conservation in Developed Lands}

Declining quality of life will have direct and indirect impacts on the sustainability of life. Land use plan will tend to increase the amount of surface runoff. The use of lands for residential purposes is correlated to flooded area and flood height for 0.849 and 0.592 , respectively. Residential use of land also has a significant influence on flooding (sig. value 0.05 ) with a correlation value of 0.795 . This value means that the greater the percentage of lands used for residential area, the greater the flood characteristics, such as area, height, or duration of flood in the lowlands of a certain region, such as Jakarta, except in the sloping to rather steep fan-shaped alluvial lands (Saud., 2007). Urban and suburban development is shown to affect flood flows to a significant degree. Improvements of the drainage system may reduce the lag time to one eighth that of the natural channels. This lag-time reduction, combined with an increased storm runoff resulting from impervious surfaces, increases the flood peaks by a factor that ranges from two to nearly eight. The flood-peak increase depends upon the drainage-basin characteristics and the flood recurrence interval (Anderson., 2001).

Development is related to land use changes which in turn are related to population activities that may cause land surface to be impervious, especially such uses as residential, social, and general facilities. The water at first will wet rock vegetation and buildings and then turn into surface runoff (Indriatmiko., 2010). Cities as centers of human activities with the highest population density will be dominated by developed lands (Rushayati et al., 2011).Developed lands will even cause the rainfall to fail to infiltrate into the ground. The rainfall that fails to infiltrate will accumulate into runoff. In the infiltration (source) areas of PZWR (Protection Zones of Water Resources), the hydrogeological structure undergoes significant water infiltration, while large volumes of groundwater accumulate in the accumulation area(Duffková., 2008). Runoff corresponding to rainfall is an important characteristic of a watershed (Bhura et al., 2015). The rainfall on developed lands will become get concentrated on the lowlands and cause floods. Flood will affect people's life and activity. Flood is one of the perennial problems in the Philippines, especially in Metro Manila. The inhabitants are affected in many aspects such as livelihood, studies, health and activities. Every time a heavy rain pours in, many activities are delayed, some are stopped others destroyed (Ganiron., 2014).

From the various cases of flood, it is found that the main cause for flooding is the rainfall that does not infiltrate. The great impacts of flood on the sustainability of life, environmental conservation becomes necessary to support life. This translates as the need for conservation in the lands utilized by the population for their activities. Conservation is closely related to the socio-economy of the inhabitants. If the land is damaged, the sustainability of the resources will decrease and eventually this will impact on the sustainability of life and development. To keep the resources sustainable, the roles of the inhabitants supported and empowered by the government are needed in doing the conservation (Sugandi., 2013). Conservation techniques such as percolation pond, check dam etc., can be recommended for better management of land and water resources for sustainable development of the watershed (Sindhu et al., 2013). Resource management, both for agricultural and various other human activities, requires an organization that considers sustainable benefits. The management can be in the forms of monitoring and planning. Agricultural and forest monitoring is a valued instrument needed by public authorities (PA) for determining land uses, planning natural resources management 
138 and collecting taxes (Nex et al., 2015). One of the impacts of environmental damage is the increased 139 surface runoff due to the failure of rainfall to infiltrate into the ground. Infiltrating water into the ground 140 will reduce the runoff volume. Departing from the problems of flood and drought above, the research 141 has formulated the following questions:

142 1. How does the area of developed lands change in Bandung Basin based on the remote sensing 143 analysis?

1442 . How much of the rainfall does not infiltrate in the developed lands of Bandung Basin?

145 3. What are the efforts of reducing surface runoff on developed lands in Bandung Basin?

146 Based on the problems formulated above, the aims of this research are as follows:

147 1. To measure the total area of land use changes in Bandung Basin with remote sensing analysis.

148 2. To measure the volume of rainfall that does not infiltrate in the developed lands of Bandung Basin using remote sensing.

3. To analyze efforts of reducing runoff volume in the developed lands of Bandung Basin.

\section{METHODOLOGY}

The research location was Bandung Basin. The basin is the upper stream of $\mathrm{Ci}$ Tarum that feeds into the distributaries and drains into the $\mathrm{Ci}$ Tarum located on Bandung plains. Bandung Basin covers the regions of Bandung City, Cimahi City, Bandung Regency, Bandung Barat Regency. Ci Tarum empties to the plains in Rancaekek and Dayeuhkolot regions.

To find about land use changes, Landsat 7 (2010) and Landsat 8 (2015) Satellite Images were used. The research employed the remote sensing method, with the following stages: Preparation, interpretation, field survey, re-interpretation, and reporting. The results of image analysis were buttressed by a survey in the field. The analysis techniques included: (a) cropping, (b) image sharpening, and (c) image classification. In the locations made as the research sample, the volumes of rain water to be infiltrated into the ground were measured from the buildings or developed lands and compared to the total area of the lands.

163 Meanwhile, flood analysis was done by measuring the flow on the surface of Bandung basin using the following formulas:

\subsection{Rainfal Intensity}

Rainfall intensity measurement formula:

\subsection{Rainfall volume}

172 The measurement of rainfall volume was evaluated by using the formula:

$$
\mathrm{R}_{\mathrm{l}} \quad=\mathrm{D} \times \mathrm{T}
$$

$R_{l}=$ Rainfall intensity ( $\mathrm{mm} /$ hour),

$\mathrm{D}=$ Rainfall duration (minute), $\mathrm{T}=$ Rain thickness.

$$
\begin{aligned}
& V=R \times A, \\
& V=\text { Volume }\left(\mathrm{m}^{3}\right), \\
& R=\text { Rainfall }(\mathrm{mm}), \\
& A=\text { Area }\left(\mathrm{km}^{2}\right) .
\end{aligned}
$$




\subsection{Land Use Changes}

179 Land use is the factor causing changes in water movement. This is so because some of the rain water 180 falling onto the land surface infiltrates, while some will flow as surface runoff, and a small amount of it 181 will evaporate. This is especially true in the lands that initially functioned to infiltrate water and then 182 were changed into lands with impervious surfaces for uses such as residential areas, roads, and other 183 impervious buildings. Land use changes cause imbalance to the environment. This imbalance cannot 184 be directly observed; however, the impacts are obvious. One of the most felt impacts is the 185 decreasing ability of the land to infiltrate water, causing the rain water to fail to infiltrate and a large 186 amount of it becomes surface runoff. When runoff water accumulates, erosion occurs and the surface 187 runoff carries soils and rock materials to the lower areas. To limit the area of Bandung Basin, the 188 analysis was done to the images of Landsat 7 (2010), resulting in a land use map of Bandung 189 Basin. The analysis of Landsat 7 (2010) and Landsat 8 (2015) images show that there are six classes 190 of land uses. Below are the results of the analysis of Landsat 2010 and 2015 images as shown in 191 figure 1 and 2.

192 Based on the image analyses displayed in figure 1 and 2, it can be observed that there are changes 193 in the total area and classes of land uses. The changes in the total area of land uses are displayed in 194 Table 1.

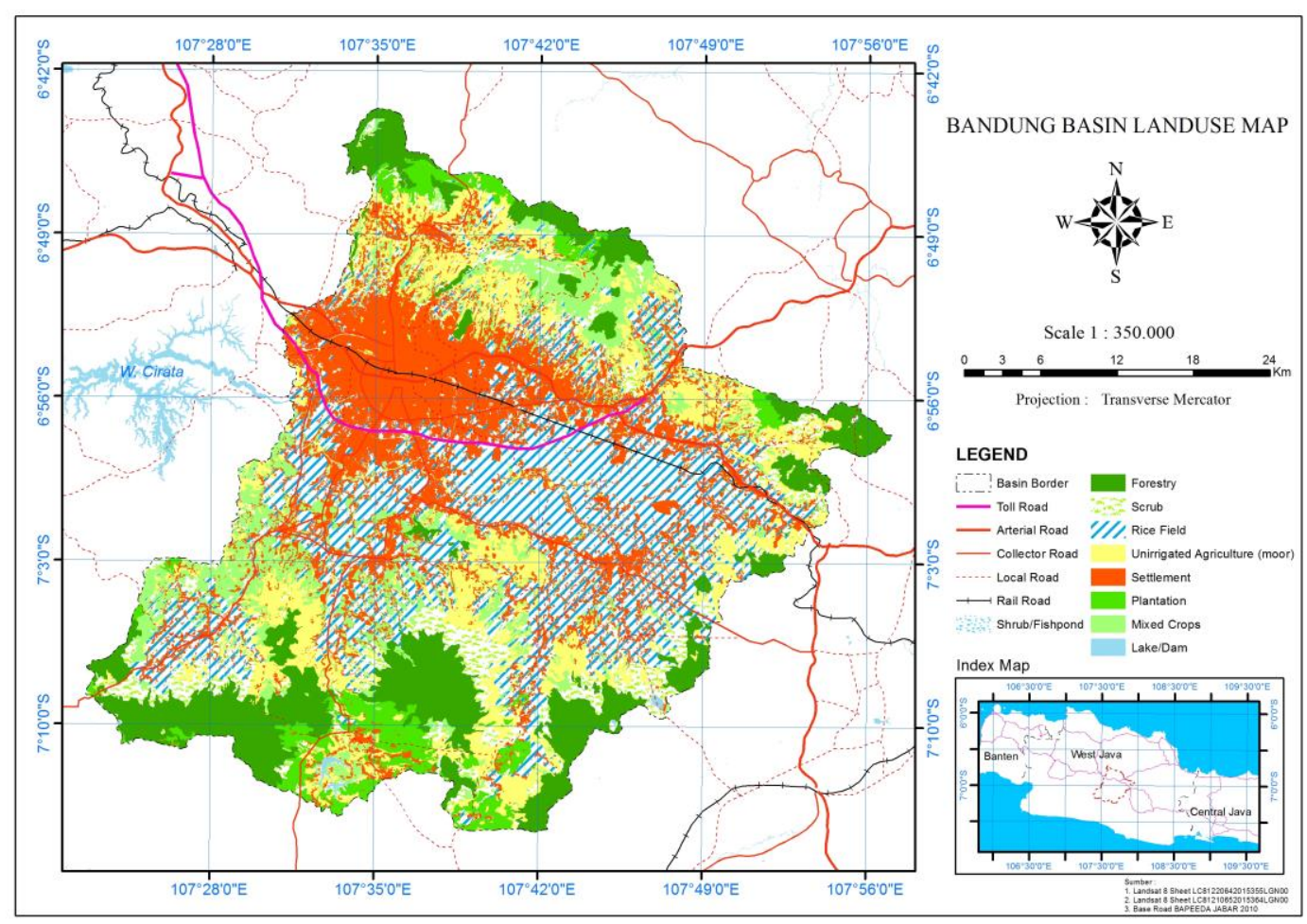

Figure 1. Land Uses in 2010 
198

202 The total area of settlement and industries as well as non-irrigated agricultural lands expanded, while 203 the total area of rice fields and forests shrank. The change affects the land surface, causing the area 204 of impervious lands to increase.

Figure 2. Land Uses in 2015

Table 1. Comparison of the Total Areas of Land Use Classes in 2010 and 2015

\begin{tabular}{|c|c|c|c|c|}
\hline \multirow[t]{2}{*}{ No } & \multirow[t]{2}{*}{ Land Use Classes } & 2010 & 2015 & \multirow{2}{*}{$\begin{array}{c}\text { Land Area } \\
\text { Change }\left(\mathrm{Km}^{2}\right)\end{array}$} \\
\hline & & Area $\left(\mathrm{Km}^{2}\right)$ & Area $\left(\mathrm{Km}^{2}\right)$ & \\
\hline 1 & Settlement and industries & 458,507 & 535,155 & $+76,648$ \\
\hline 2 & Brushes & 121,337 & 129,272 & $+7,935$ \\
\hline 3 & Plantation & 82,681 & 85,580 & $+2,899$ \\
\hline 4 & Mixed gardens & 182,685 & 182,489 & -196 \\
\hline 5 & Forests & 265,927 & 249,243 & $-16,684$ \\
\hline 6 & Non-irrigated agricultural lands & 282,569 & 395,448 & $+112,879$ \\
\hline 7 & Rice fields & 517,791 & 334,310 & $-183,481$ \\
\hline & Total Area & $1,911,498$ & $1,911,498$ & \\
\hline
\end{tabular}

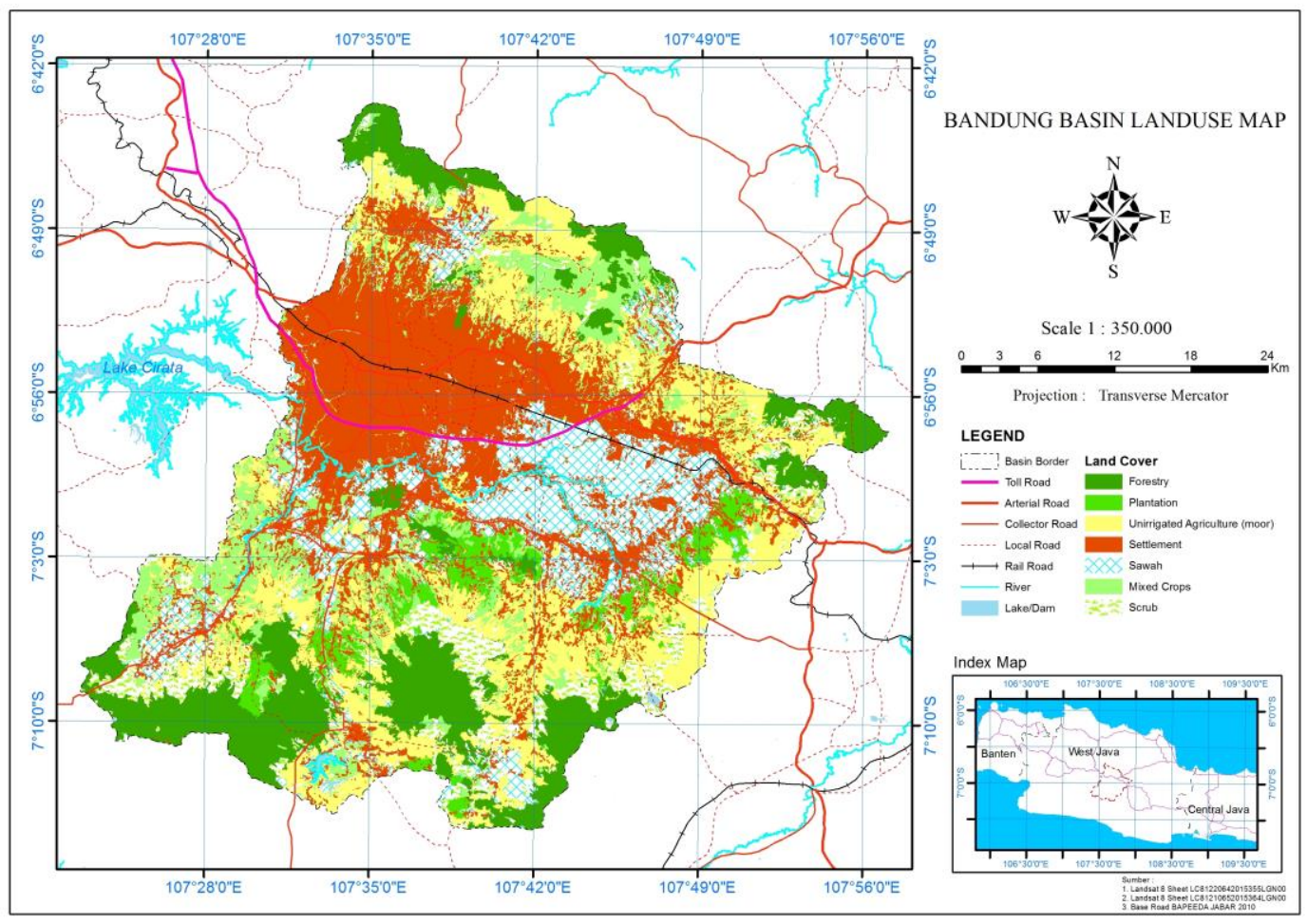

\begin{tabular}{|l|c|c|c|c|c|c|c|c|c|c|c|c|}
\hline Station & Jan & Feb & Mar & Apr & May & Jun & Jul & Aug & Sep & Oct & Nov & Dec \\
\hline Lembang & 142.1 & 221.9 & 201.8 & 204.1 & 178.5 & 62.2 & 62.0 & 26.9 & 60.8 & 104.5 & 299.0 & 262.3 \\
\hline Cisondari & 142.1 & 170.2 & 158.6 & 151 & 152.6 & 50.7 & 26.2 & 22.4 & 40.2 & 76.3 & 168.4 & 192.3 \\
\hline Cileunca & 241.0 & 268.7 & 266.8 & 265 & 133.8 & 57.9 & 35 & 37 & 52.7 & 118.2 & 292.0 & 336.9 \\
\hline Rainfall & 175.1 & 220.2 & 209.1 & 206.7 & 155.0 & 56.9 & 41.1 & 28.8 & 51.2 & 99.7 & 253.1 & 263.8 \\
\hline $\begin{array}{l}\text { Days of } \\
\text { Rain }\end{array}$ & 16 & 16 & 15 & 16 & 7 & 3 & 2 & 2 & 2 & 4 & 13 & 15 \\
\hline Rain/day & 10.9 & 13.8 & 13.9 & 12.9 & 22.1 & 19 & 20.5 & 14.4 & 25.6 & 24.9 & 19.5 & 17.6 \\
\hline
\end{tabular}

210 Source: Department of Public Work (Rainfall Data, 2016). 
211 The lowest rainfall was observed in July, ranging for $35 \mathrm{~mm} /$ day and the highest was in December for $212336 \mathrm{~mm} /$ day in Cileunca, Pangalengan. The rate of the rainfall should be calculated in the unit of 213 hour; hence, it was divided into 24 hours. When calculated in a 24 hour unit, the rain intensity seems 214 to be small; however, the small rain intensity will get concentrated in the plains into a large volume.

Table 3. Runoff Volumes in Bandung Basin

\begin{tabular}{|c|c|c|c|c|c|}
\hline Month & $\begin{array}{l}\text { Rainfall } \\
\text { (mm/day) }\end{array}$ & $\begin{array}{l}\text { Developed Land } \\
\left(\mathrm{m}^{2}\right) 2010\end{array}$ & Volume $\left(\mathrm{m}^{3}\right)$ & $\begin{array}{l}\text { Developed Land } \\
\left(\mathrm{m}^{2}\right) 2015\end{array}$ & Volume $\left(\mathrm{m}^{3}\right)$ \\
\hline January & 10.9 & \multirow{12}{*}{458507000} & $4,997,726.30$ & \multirow{12}{*}{535155000} & $5,833,189.50$ \\
\hline February & 13.8 & & $6,327,396.60$ & & $7,385,139.00$ \\
\hline March & 13.9 & & $6,373,247.30$ & & $7,438,654.50$ \\
\hline April & 12.9 & & $5,914,740.30$ & & $6,903,499.50$ \\
\hline May & 22.1 & & $10,133,004.70$ & & $11,826,925.50$ \\
\hline June & 19 & & $8,711,633.00$ & & $10,167,945.00$ \\
\hline July & 20.5 & & $9,399,393.50$ & & $10,970,677.50$ \\
\hline August & 14.4 & & $6,602,500.80$ & & $7,706,232.00$ \\
\hline September & 25.6 & & $11,737,779.20$ & & $13,699,968.00$ \\
\hline October & 24.9 & & $11,416,824.30$ & & $13,325,359.50$ \\
\hline November & 19.5 & & $8,940,886.50$ & & $10,435,522.50$ \\
\hline December & 17.6 & & $8,069,723.20$ & & $9,418,728.00$ \\
\hline
\end{tabular}

216 Runoff will cause monthly flood. Efforts of reducing the increased runoff volume should be made in 217 each smallest land unit. The area of the smallest land unit that is assumed to be quite representative 218 is $100 \mathrm{~m}^{2}$.

\subsection{Increasing Infiltration}

220 The runoff of rain water should infiltrate into the ground. However, because the lands are impervious, the rain water turns into surface runoff. The smallest land unit, $100 \mathrm{~m}^{2}$ in size, should take into account the volume of runoff in order to easily calculate the amount of water to be infiltrated. The runoff volumes in each $100 \mathrm{~m}^{2}$ land unit are shown in Table 4.

Table 4. Runoff Volumes for every $100 \mathrm{~m}^{2}$ Land Unit (2010)

\begin{tabular}{|l|c|c|c|c|c|}
\hline Month & Volume $\left(\mathrm{m}^{3}\right)$ & $\begin{array}{l}\text { Developed } \\
\text { Lands }\left(\mathrm{m}^{2}\right)\end{array}$ & $\begin{array}{l}\text { Infiltrated } \\
\text { Water Volume } \\
\left(\mathrm{m}^{3}\right)\end{array}$ & $\begin{array}{l}\text { Duration of } \\
\text { Rain (hour) }\end{array}$ & $\begin{array}{c}\text { Infiltration } \\
\text { Wells }\left(\mathrm{m}^{3}\right)\end{array}$ \\
\hline January & $5,833,189.50$ & $5,351,550$ & 1.09 & 5 & 5.45 \\
\hline February & $7,385,139.00$ & $5,351,550$ & 1.38 & 5 & 6.9 \\
\hline March & $7,438,654.50$ & $5,351,550$ & 1.39 & 5 & 6.95 \\
\hline April & $6,903,499.50$ & $5,351,550$ & 1.29 & 5 & 6.45 \\
\hline May & $11,826,925.50$ & $5,351,550$ & 2.21 & 5 & 11.05 \\
\hline June & $10,167,945.00$ & $5,351,550$ & 1.9 & 5 & 9.5 \\
\hline July & $10,970,677.50$ & $5,351,550$ & 2.05 & 5 & 10.25 \\
\hline August & $7,706,232.00$ & $5,351,550$ & 1.44 & 5 & 7.2 \\
\hline September & $13,699,968.00$ & $5,351,550$ & 2.56 & 5 & 12.8 \\
\hline October & $13,325,359.50$ & $5.351,550$ & 2.49 & 5 & 12.45 \\
\hline November & $10,435,522.50$ & $5,351,550$ & 1.95 & 5 & 9.75 \\
\hline December & $9,418,728.00$ & $5,351.550$ & 1.76 & 5 & 8.8 \\
\hline
\end{tabular}

225

226

227

228

229

230

231

Each $100 \mathrm{~m}^{2}$ unit of land should save rainfall volume in the range of $5.45 \mathrm{~m}^{2}-12.45 \mathrm{~m}^{2}$ with an average of $8.96 \mathrm{~m}^{2}$. This means that the developed lands in each smallest unit should save around $8.96 \mathrm{~m}^{2}$ rainfall. To infiltrate rainfall into the smallest building unit is done by making an infiltration well that can collect as much as $8.96 \mathrm{~m}^{2}$ water. By making infiltration wells, rainfall will not turn into surface runoff.

\section{DISCUSSION AND CONCLUSION}


232 The analysis of Landsat 7and 8, images show that there are seven classes of land use. The land use 233 changes that experience expansion are: settlement and industries $\left(+76.69 \mathrm{Km}^{2}\right)$, non-irrigated 234 agricultural lands $\left(+112.88 \mathrm{~km}^{2}\right)$, brushes $\left(+7.935 \mathrm{~km}^{2}\right)$, and plantations $\left(+2.899 \mathrm{~km}^{2}\right)$, while the lands 235 undergoing shrinking are those intended for such uses as: Mixed gardens $\left(-196 \mathrm{~km}^{2}\right)$, forests $(-16.68$ $\left.\mathrm{km}^{2}\right)$, and rice fields $\left(-183.48 \mathrm{~km}^{2}\right)$. The land use change for settlement causes surface runoff, while the change for non-irrigated agricultural lands increases erosion, and the flow carries eroded materials because the majority of the lands are open areas. The land use change in brushes causes runoff as well because the lands become impermeable. Meanwhile, changes in plantations cause erosion and runoff because the areas under the tree canopies become exposed. The effects caused by the shrinking areas are as follows: Shrinking forests cause increased runoff; shrinking mixed gardens cause erosion and runoff because the lands become open lands; and shrinking rice fields cause runoff.

A change from undeveloped to developed lands results in an increase of surface runoff. The total area of developed lands in 2010 was $458,507,000 \mathrm{~m}^{2}$, with the highest rainfall in September (25.6 $\mathrm{mm}$ ), so the largest runoff volume was $11,737,779.200 \mathrm{~m}^{3}$. A land with an area of $535,155,000 \mathrm{~m}^{2}$ with the same precipitation rate will cause runoff volume of $13,699,968.00 \mathrm{~m}^{3}$. The runoff of rain water will create a disaster when it gets concentrated. Because runoff flows to lower areas, flood disasters in Bandung Basin are usually found in regions such as Dayeuhkolot, Majalaya, and Rancaekek. The large volume of runoff does not match the river's capacity, so that to reduce the runoff even the smallest unit of land needs to be utilized. The smallest unit of land assumed to be representative is that with a size of $100 \mathrm{~m}^{2}$. This means that each land unit should infiltrate the rainfall in order to avoid surface runoff.

Because the average rainfall volume is $8.96 \mathrm{~m}^{2}$, then it means that the developed lands should save around $8.96 \mathrm{~m}^{2}$ rainfall. To infiltrate rainfall into the smallest unit of building, an infiltration well with the capacity of $8.96 \mathrm{~m}^{2}$ should be built. The infiltration well should be $8.96 \mathrm{~m}$ in depth and $1 \mathrm{~m}$ in diameter. Only then the rainfall on the developed lands will not turn into runoff. The analysis of Landsat 7 (2010) and Landsat 8 (2015) images show land use changes in Bandung Basin. These changes have reduced the infiltration of rainfall, thus increasing surface runoff. The total area of developed lands in 2010 was $458,507,000 \mathrm{~m}^{2}$, while in 2015 it expanded to $535,155,000 \mathrm{~m}^{2}$. This expansion has caused an increase in the runoff volume from $11,737,779.200 \mathrm{~m}^{3}$ in 2010 to 13,699,968.00 $\mathrm{m}^{3}$ in 2015.

An increase in the runoff volume has caused an increase in the flood volume in Dayeuhkolot, Majalaya, and Rancaekek regions. To reduce the runoff volume, efforts of infiltrating rainfall into the ground by means of building infiltration wells are needed. The infiltration wells should have the capacity of $8.96 \mathrm{~m}^{3}$. Hence, the rainfall will not potentially result in surface runoff. To solve the problems of runoff, the regional governments have to hold extensions and make policies regulating building/development permits. With policies in developing settlement and industrial areas, the potential of rainfall to cause runoff will be greatly reduced.

\section{REFERENCES}

6. Paragraph: Margin: Left=1 inch, Right=1 inch, Font: size10 pt. Font Face =Arial, Align= justify, Line Space $=$ single $p t$. 
Bhura, C.S., Singh, N.P., Mori, P.R, Prakash, I, Mehmood, K, 2015, Estimation of Surface Runoff For

278 Ahmedabad Urban Area using SCS-CN Method and GIS. International Journal of Science 279 Technology \& Engineering. 1, 411-416.

280 Department of Public Works, 2016, Data Curah Hujan (Rainfall Data), Department of Public Works, 281 Waterworks, Bandung, West Java.

282 Duffková, R, 2008, Evaluation of Management-Dependent Changes in the Water Regime of Extensive 283 Grasslands. Journal of Soil \& Water Res, 3, 1-11.

284 Enger, E.E., Smith, B.F.V., Bockarie, A.T, 2006,. Environment Science: A Study of Interrelationship, tenth edition, New York: McGraw Hill International Edition.

286 Ganiron, Jr, T.U, 2014, An Analysis of the Public Perception of Floods in Manila City. International Journal of Disaster Recovery and Business Continuity, 5, 1-14.

Gogate, N.G., Rawal, P.M, 2015, Identification of Potential Stormwater Recharge Zones in Dense Urban, Context: A Case Study from Pune city. International Journal of Environment Resources, 9, 1259-1268.

Habiyakare, T., Nianqing, Z., and Xinping, S. (2015). Assessment of contribution of major rivers inflow into the Dongting Lake, China, International Journal of Water Resources and Environmental Engineering, 7, 109-114.

Haque, M.Z., Reza, M.I.H., Rahim, S.A., Abdullah, M.P., Elfithri, R., Mokhtar, M, 2015, Behavioral Change Due To Climate Change Effects Accelerate Tiger Human Conflicts: A Study On Sundarbans Mangrove Forests, Bangladesh. International Journal of Conservation Science, 6, 669-684.

Idowu, T.O., Edan, J.D., Damuya, S.T, 2013, Estimation of the Quantity of Surface Runoff to Determine Appropriate Location and Size of Drainage Structures in Jimeta Metropolis, Adamawa State, Nigeria, Journal of Geography and Earth Science, 1, 19-29.

300 Indriatmiko, H.I, 2010, Penerapan Prinsip Kebijakan Zero Delta Q dalam Pembangunan Wilayah 301 (Implementing the principles of Zero Delta $Q$ policies in area development), Pusat Teknologi 302 Lingkungan, BPPT, JAI, 6, 77-83.

303 Iskandar, D., Sugandi, D 2015, Flood Mitigation Efforts In The Special Capital Region Of Jakarta, 304 International Journal Of Conservation Science, 6, 685-696.

Klijn, F., Kreibich, H., De Moel, H., Rowsell E.P, 2015, Adaptive flood risk management planning based on a comprehensive flood risk conceptualization. Mitigation Adapt Strateg Glob. Change, 20, 845-864.

308 Koyari, E., Priyantoro., Sisinggih, D, 2012, Pola Pengendalian Banjir Kawasan Bambu Kuning Kota 309 Jayapura. Jurnal Teknik Pengairan, 3, 240-249.

310 Meyer, B.W., Turner, B.L, 1998, Change in Land Use and Land Cover (A Global Perspective), 311 Cambridge University Press, United Kingdom.

312 Mohsen, M., Iqbal, Z., Kumar, U., Ullah, W., Akash, O 2013, Sustainable System Solutions: RAK

313 Research and Innovation Center, International Journal of Sustainable Water \& Environmental 314 Systems, 5, 67-76.

315 Nex, F., Delucchi, L., Gianelle, D., Neteler, M., Remondino, F., and Dalponte, M, 2015, Land Cover 316 Classification and Monitoring: the STEM Open Source Solution, European Journal of Remote 317 Sensing, 48, 811-831.

318 Prakash, C.R., Asra, M., Venkatesh, J., Sreedevi, B, 2015, Monitoring Urban Land-Cover Features 319 using Resourcesat LISS-III Data, International Journal of Advanced Remote Sensing and GIS, 4, 320 1064-1069.

321 Prasena, A., Shrestha, P, 2013, Assessing The Effects of Land Use Change On Runoff In Bedog 322 Sub-Watershed Yogyakarta, Faculty of Geography UGM, Indonesian Journal Geography, 45, 48-61.

323 Putro, S., Hayati, R, 2007, Dampak Perkembangan Permukiman Terhadap Perluasan Banjir 324 Genangan Di Kota Semarang, Jurnal Geografi UNNES, 4, 35-43.

325 Rushayati, S.B., Alikodra, H.S, Dahlan, E.N., Purnomo, H, 2011, Pengembangan Ruang Terbuka 326 Hijau Berdasarkan Distribusi Suhu Permukaan Di Kabupaten Bandung (Developing green open 
space based on surface temperature distribution in Bandung Regency). Jurnal Forum Geografi, 25, 17-26.

329 Sanayanbi, H., Zaphu, V.V., Monica, N., Vanlalremruatpuii, T.B.C., and Bandyopadhyay, A. (2014).

330 Vulnerability Assessment of Arunachal Pradesh to Floods. International Journal of Innovative

331 Research in Science, Engineering and Technology,.3, 81-92.

332 Saud, I, 2007, Kajian Penanggulangan Banjir di Wilayah Pematusan Surabaya Barat (A study of flood 333 mitigation in Pematusan, West Surabaya), Jurnal Aplikasi, 3, 1-9.

334 Sanjay, J., Jaivir, T., Vishal, S, 2010, Simulation of Runoff and Sediment Yield for a Himalayan Watershed Using SWAT model, Journal of Water Resource and Protection, 2, 276-281.

336 Sawant, V.R, 2013, Integrated Flood Management in Urban Flooding. International Journal of 337 Research and Development-A Management Review, 2, 13-16.

338 Scholz, M. (2013). Sustainable Water Systems. Journal of Water, 5, 239-242.

339 Sefouhi, L., Kalla, M., Aouragh, L, 2010, Trends and Problems of Municipal Solid. International 340 Journal of Sustainable Water \& Environmental Systems, 1, 15-20.

341 Sindhu, D., Shivakumar, B.L., Ravikumar, A.S, 2013, Estimation Of Surface Runoff In Nallur 342 Amanikere Watershed Using Scs-Cn Method, International Journal of Research in Engineering and 343 Technology, Conference Issue, eISSN: 2319-1163 | pISSN: 2321-7308, 404-409.

344 Singh, M., Sinha, A.K., and Singh, P, 2014, Maintaining The Biodiversity of Informal Protected Areas: 345 A Collaborative Conservational Approach, International Journal Of Conservation Science, 5, 107-116.

346 Smith, K., and Ward, R. (1998). Floods, Physical Processes and Human Impacts. Chichester, USA: 347 John Wiley \& Sons Ltd.

348 Sukojo, B.M, 2013, Penggunaan Metode Analisa Ekologi dan Penginderaan Jauh Untuk 349 Pembangunan System Informasi Geografis Ekosistem Pantai. Jurnal MAKARA, Sains, 7, 32-37.

350 Sugandi, D, 2014, A Model of Environmental Conservation For Sagara Anakan, International Journal of Conservation Science, 5, 95-106.

352 Sugandi, D, 2013, Environmental Education and Community Participation: The Importance of 353 Conservation Lessons in Teaching and Learning for Environmental Conservation Efforts in the 354 Region of Sagara Anakan, SosioHumanika, Jurnal Pendidikan Sains Sosial dan Kemanusiaan, 6, 355 183-193.

356 Waters, S., Farrell-Poe, K., Wagner, K, 2011, When it Rains it Runs Off: Runoff and Urbanized Areas in Arizona. Arizona Cooperative Extension, The University of Arizona, 1-5.

358 Weng, Q, 2001, Modeling Urban Growth Effects on Surface Runoff with the Integration of Remote 359 Sensing and GIS, Journal of Environmental Management, 28, 737-748.

360 Wiryono, 2007, Menuju Pembangunan Berkelanjutan, Membangun Tanpa Merusak Lingkungan 361 (Towards sustainable development, developing without damaging the environment), Seminar 362 Pembangunan Berkelanjutan, Bengkulu, Universitas Bengkulu.

363 Tambunan M.P, 2014, Kaitan Penggunaan Lahan Perkotaan dengan Banjir (The relationship between 364 urban land use and flood), Departemen Geografi, FMIPA Universitas Indonesia [online], avalaible: 365 http://geografi.ui.ac.id/portal/ sivitas-geografi/dosen/ makalah-seminar/kaitan-penggunaan-lahanperkotaan-dengan-banjir/, acceced, October $13^{\text {th }} 2014$. 